\title{
演題番号 27
}

\section{人工心肺装置のローラーポンプに同期して発生した 心電図アーチファクトに対する検討と対策 （第二報）}

\author{
埼玉県立小児医療センター $\mathrm{ME}$ 室 \\ 松井晃小池龍平 \\ 同麻酔 科 \\ 鈴 木 美佐子 \\ 同心臓外科 \\ 鈴木和彦中村譲松井道彦 \\ 三井記念病院 MEサービス部 \\ 小野哲 章
}

はじめに

開心術中に於ける心電モニタリングは，必要不 可欠なむのであるが，人工心肺運転中に，特異な アーチファクトに遭遇することが多く，術中心電

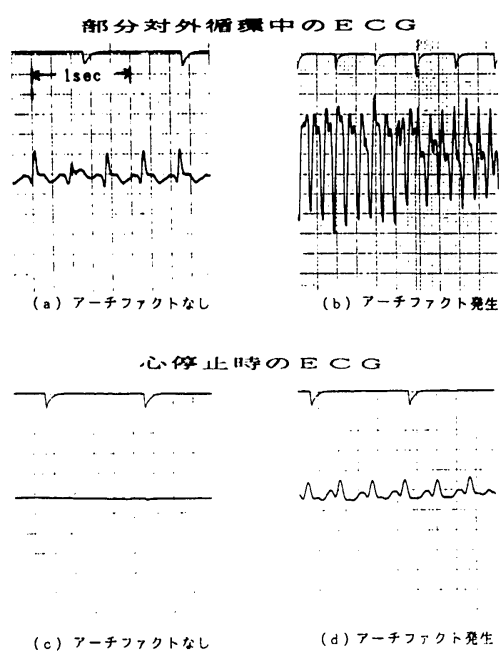

図 1 部分体外循環中のECDと 心停止時のECD
モニタリングに支障を来すことが度々あった．図 1 の(a)は部分体外循環中の心電波形であり，(b)は (a)の心電波形上に発生したアーチファクトである. (c)は心停止時の波形であり，(d)は心停止時に発生 したアーチファクトである. このアーチファクト の波形は一定ではなく，様々な形で発生する.

当研究会の第九回大会にて，てのアーチファク 卜の原因は, 人工心肺装置のローラーポンプと， ポンプチューブとの摩擦によって発生する, 静電 気であると報告したが，今回，静電気測定機にて，

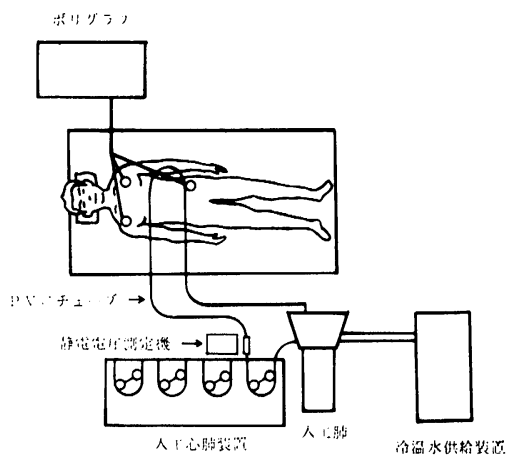

図 2 実験概略図 
静電電圧を測定し，このアーチファクトの対策に ついて検討したので報告する．

\section{実酫方法}

実険方法は図 2 のように，COB E 社製VP CML人工肺, Sarns 社製7000MDX人心肺 装置，PVCチューブにて構成された回路に血液 を満たした：そして，回路の一端より，乙の血液 に被検者が直接触れるようにした。 また, 冷温水 供給装置を人工肺に接続できるようにした。 また， PVCチューブのローラーポンプの出口側に金属 管を接続し， $4 \mathrm{~cm} \times 5 \mathrm{~cm}$ のアルミ箔を装着した。 この部位より，シムコ社製静電気測定機 S S - 2 型にて静電電质を测定した。(写真 1 )。心電図モ ニターとして，フローティングタイプのポリグラ フ, 日本光電社製 $M R-6000$ を使用した.

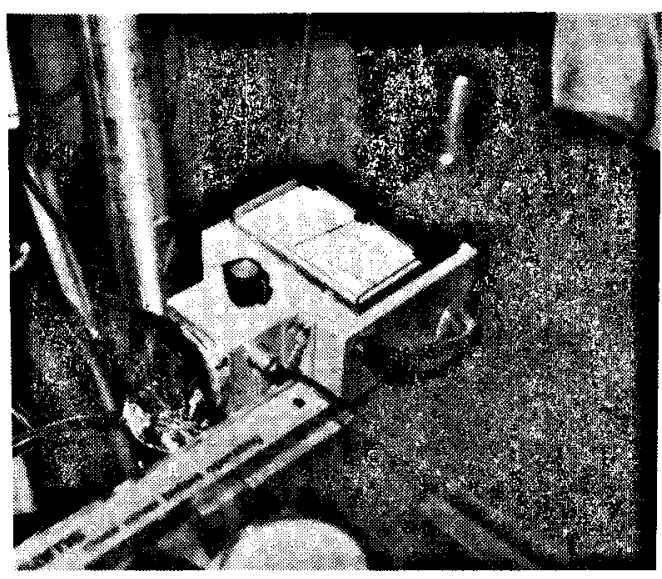

写基 1

\section{結果およひ考察}

図 3 は, ポンプの回転数を変化させた時の静電 電圧の変化を見たものである. ポンプの回転数と ともに, 静電電圧が上昇しているが, 点線で囲っ た部分の変動成分は，ポンプ回転数が増加しても 静電電圧の上昇は少ない，ポンプ回転数 $100 \mathrm{rpm}$ では, 非変動成分 $800 \mathrm{~V}$, 変動成分 $200 \mathrm{~V}$, 平均 で $900 \mathrm{~V}$ の静電電圧が発生している.

図 4 は，ポンプ回転数を $100 \mathrm{rpm}$ とた時に, 被検者とアース間の抵抗を， $\infty, 10 \mathrm{M} \Omega, 5 \mathrm{M} \Omega$,

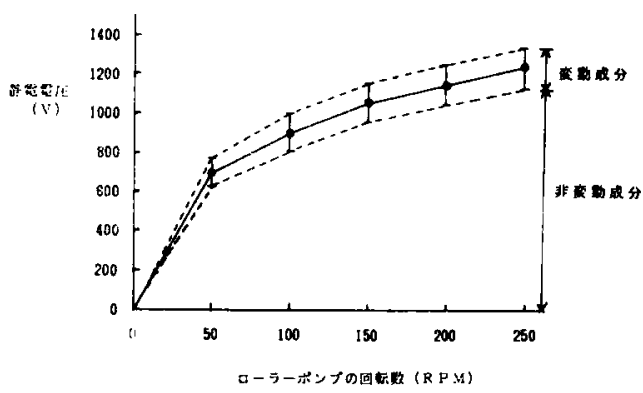

図3 ポンプ回転数と觧再后の変化

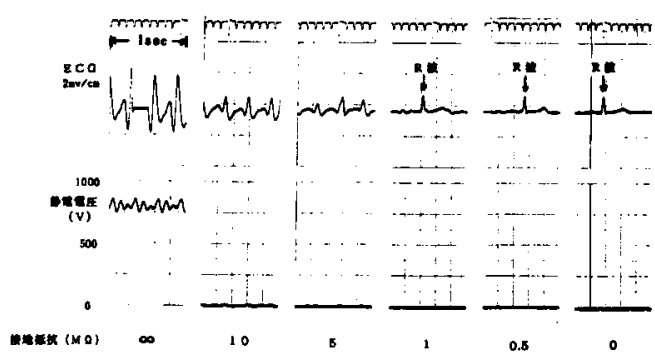

図4接地抵抗の変化におけるアーチファクトの変化

$1 \mathrm{M} \Omega, \quad 0.5 \mathrm{M} \Omega, 0 \Omega$ と変化させた時の心電図 之静電電王である. 抵抗 $\infty$ の時では, 被検者の心 電図R波 $1 \mathrm{mV}$ に対し， $4 \mathrm{mV}$ のアーチフアクトが 発生し，心電闵が確認できない，乙の時の静電電 圧は, 非変動成分 $750 \mathrm{~V}$ と変動成分 $120 \mathrm{~V}$ で, 平 均 810 Vの静電電圧が発生していた。心臓外科沉 使用される心電モニターは, 患者の安全のために フローティング型が使用される.このタイプの心 電モニターでは，患者とアース間が絶縁された形 となり, 発生した静電気の逃げ道が無くなる. こ のため, 身体に帯電した静電気の変動が, 心電図 上にアーチファクトとして出現していると考えら れる. 被検者とアース間の抵抗を小さくするに従

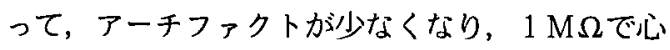

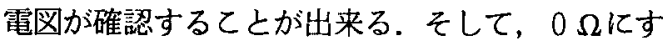
ると,アーチファクトは消失し，静電電圧は $0 \mathrm{~V}$ となる。しかし，患者を接地すると言うことは, 患者に装着されているME機器からの漏れ電流が あった場合，ミクロショック等の危険がある.そ こで, 患者とアース間には, 出来るだけ高い抵抗 を挿入することが望ましい。 

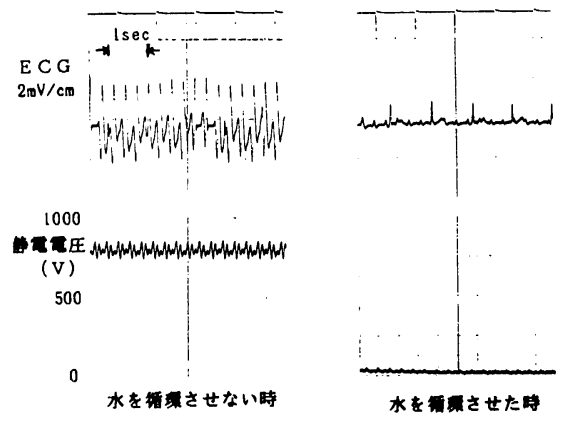

図 5 人工肺に水を循環させた時と

図 5 は, 冷温水供給装置にて人工肺に水を循環 させた時と, 循環させない時の比較上静電電圧であ る. 右の人工肺に水を循環させた時では, 心電図 には $0.4 \mathrm{mV}$ のアーチファクトが発生するが, $\mathrm{R}$ 波は確認できる程度である. そして静電電圧は, 変動成分の $30 \mathrm{~V}$ が測定された. 人工肺には, ステ ンレス製の熱交換器があるが，人工肺に冷温水供 給装置を接続し，水を循環させた時の人工肺とア 一ス間の, インピーダンスを測定した結果, 対地 抵抗は $0.5 \sim 1.5 \mathrm{M} \Omega$ と他のME機器に比べて著し く低くかった。 ステンレス管の外側を血液が流れ， 内側を泠温水供給装置からの水が循環することで, 冷温水供給装置のタンクがアースされているため に, 静電気がアースに落ちてアーチファクトが減
少したと考えられる. しかし，水を循環させても アーチファクトが減少しないととあ度々あり, 術 中にアーチファクトが発生するてとになる。乙の 原因として，循環させる水の組成等が考えられる。 臨床時に扔いて, 静電電圧の測定を行ったが, アーチファクトが発生している時の静電電圧は, 変動成分の $20 \sim 40 \mathrm{~V}$ 程度であった. 臨床では, 血 液回路が患者に直接接触しているため, 実験時よ りあ大きなアーチファクトが発生すると考えられ るが, 多数のME機器や患者周辺の人や物を介し て, 静電気が逃げるために, 臨床時の静電電圧は かなり低くなっていると考えられる。

\section{結 語}

1. 実験において, ポンプ回転数 $100 \mathrm{rpm}$ の時の

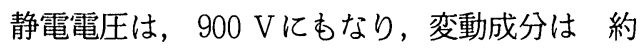
200 Vであった.

2. 冷温水供給装置にて人工肺に水を循環させる とアーチファクトが減少する場合があるが, 確 実ではない.

3. ミクロショック等を考えると, 患者とアース 間には，1 $\mathrm{M} \Omega$ 程度の抵抗を插入するてとが望 ましい.しかし，患者をアースするととが最む 簡単で確実な方法であるため, 我々は心臓が停 止してから患者に直接アースするてとにしてい る. 